\title{
Kinnier Wilson's notes of conversations with Hughlings Jackson
}

\author{
J. PURDON MARTIN
}

The notes which follow have recently come to light, nearly 70 years after they were written, and I believe they are unique in the sense that, while much has been written about Hughlings Jackson's ideas, no other record, as far as I know, exists of his conversation. Perhaps the nearest things that we have in print are the examples of some of Jackson's pithy expressions given by Dr Critchley in one of his essays (Critchley, 1964).

Kinnier Wilson collected many reprints of Jackson's papers and three thin bound volumes of them are included in the generous gift of his father's books which Dr Bruce Kinnier Wilson has made to the Neurological Departmental Library (The Cairns Library) at Oxford, and these typewritten notes are bound in as a preface to one of these volumes.

In the summer of 1906, when the recorded conversations took place, Dr Jackson was almost at the end of his professional career; he was 71 years old and he retired finally from the National Hospital, Queen Square, before the year was out. Thereafter his health was poor and he died in 1911.

Wilson at this time was aged 28. Having taken his medical degrees at Edinburgh, he had been house-physician there to Sir Byrom Bramwell and afterwards spent a period in Paris before being appointed 'to the house' at Queen Square in 1904. He was thus one of the last of Hughlings Jackson's house-physicians, and eventually the last of his pupils to be appointed to the honorary staff of the hospital. He made a world-wide reputation six years later when he described the rare disease which bears his name, and which he called progressive lenticular degeneration. Always a good talker, he was an interesting conversationalist and a brilliant teacher, though moody. Incidentally, for a good many years he was the editor of the Journal of Neurology and (Accepted 4 December 1974.)
Psychopathology, which, in fact, was widely known as Wilson's Journal. ${ }^{1}$ He died in 1937. Jackson always drove about in an open landau with a pair of horses, and those drives on summer afternoons must have been very pleasant.

\section{I}

On the occasion of the first conversation recorded by Wilson the destination was Highgate Infirmary. This is now the Highgate Wing of the Whittington Hospital, and is situated on the slope of the Northern Heights, halfway up Highgate Hill, the entrance actually being in Dartmouth Park Hill and the journey from Queen Square by horse vehicle would probably take about three-quarters of an hour.

\section{ON A JOURNEY TO HIGHGATE}

\section{S. A. KINNIER WILSON:}

'IN CONVERSATION WITH DR HUGHLINGS JACKSON, 21 June 1906, en route for Highgate Infirmary'.

He told the story of an Irishman who dreamt that he was supping with the Pope. The latter asked him whether he would have his whisky hot or cold. Pat said hot and so the kettle was put on the fire. Unfortunately he woke up before the kettle boiled, and thereafter never ceased regretting that he had not asked for his whisky cold.

1 The Review of Neurology and Psychiatry was founded in 1903 by Alexander Bruce and ran until volume 16, 1918, at which time Bruce's son, Ninian, was editor and Kinnier Wilson, his son in law, was one of the assistant editors. After the 1914-18 war it was decided to institute a new journal in succession to the Review, the Journal of Neurology and Psychopathology, and Kinnier Wilson was asked to become its editor, continuing in that office up to his death. The journal was published by John Wright and Sons, Ltd, Bristol, until 1921 when, under the same title, it was published in London by Heinemann (Medical Books) Ltd, and later, from 1926, by the British Medical Association. The first volume in a new series under the title of Journal of Neurology and Psychiatry appeared in 1938. After Wilson's death, Dr E. A. Carmichael became editor, and the new developments brought about by the war enforced another change of title in 1944 to the journal's present form, the Journal of Neurology, Neurosurgery, and Psychiatry. In 1947 Dr Carmichael resigned and W. Ritchie Russell was appointed to head the editorial committee. He then served as editor for 21 years. Editor. 
Dr J. said the story was of considerable psychological interest.

He said a fancy of his was the following:

'If I had a right hemiplegia, I should wish the greatest incidence to be on the leg, but if I had a left hemiplegia, I should wish the least incidence to be on the leg, assuming, of course, that I am right handed.'

He was talking of movements being represented in the cortex, and not individual muscles, and he said it was exactly similar to the difference between notes of music and tunes; the cortex has a memory only for tunes, never for notes. There are two different tunes from the same notes, cortical, i.e. cerebral, and cerebellar.

He talked a good deal of the impossibility of positive symptoms from negative lesions, and emphasized the far-reaching significance of the doctrine. The sclerosis of the posterior columns in tabes can never be the cause of the pains or the ataxia. Absence of fibres can never give rise to such symptoms. The tabetic does his best to walk with what of his nervous system he has left. The same is true of mental diseases. Mental disease causes negative symptoms only, positive symptoms come from the part of her or his brain that is left. Where all is negative, a condition of complete dementia is reached. He mentioned the case of a patient of his with delusions, who once said she was going in a boat with cats to meet her Saviour in the air. He pointed out not merely the absurdity but the complexity of the idea; it came from that part of her brain that was left, and it was the complexity of the delusion that was so important.

Another case was a man who used to say, 'light that fire up there', referring to the gas. He did not know that it was a gas light because of the disease of his brain, but he thought it was a fire with what remained of his cortex.

He mentioned a woman with delusions, who as she lay in hospital heard some workmen outside hammering and said, 'Ah, they are putting up a scaffold to hang me; I am going to be hanged'. Here the rational way in which she got the idea showed that it emanated from the part of her brain that was unaffected.

Emerson was aphasic before he died and used to ask for the arrangement with four legs on which things are put. He had lost the word 'table'. Here the difference between the functioning and non-functioning part of the brain is clearly seen.

We began to talk of 'spoonerisms', and he instanced the case of the man who said 'toffy cavern' instead of 'coffee tavern'. His view was that the two halves of the brain are not cooperating harmoniously when such a thing occurs. He pointed out that it was more than a mere transposition of the first letters. He referred to the difference between verbalizing and propositionizing. Spelling is obviously an accident, and has nothing to do with the word. Before we can say a word, we must have it in our minds, but its spelling has nothing to do with it. Cat might have been spelled kat.

There may be a 'spoonerism' of thought or of idea, apart from letters or words. A man once went to see a dentist and was rather flurried at the prospect. The latter said, 'Open your mouth and I shall put my finger in', but the fellow at once replied, 'Oh no, you might bite it'.

I remarked on the flow of his ideas, and he said they just came to him as the result of unconscious cerebration. It is always so. What one has to do is to read and work as much as one can, and then allow one's mind to do the rest. We talk popularly of sleeping over a problem or a question.

A brilliant Scots law student used to read all his cases in the evening, drink his share of whisky, then go to bed. All combined 'whummelled in his wame' by night, and in the morning everything was clear Unconscious cerebration did it.

\section{II}

A week later the pair went to Marylebone Infirmary-now St Charles's Hospital. It is situated in North Kensington, at the top of Ladbroke Grove, and the drive from Queen Square would have been somewhat longer than that to Highgate.

\section{ON THE WAY TO NORTH KENSINGTON}

\section{S. A. KINNIER WILSON:}

'IN CONVERSATION WITH DR HUGHLINGS JACKSON, 28 June 1906, en route for Marylebone Infirmary'. He said of Carlyle that much of his writing was simply glorified swearing, swearing to a very high power.

Titus Oates was his favourite scamp. If Titus Oates is not in hell then they had better get a new devil who knows his business.

We were talking of a crime which had just occurred in New York, where a man had shot another in a place of amusement. Dr Jackson said it was not so much the enormity of the crime as the absurdity of it that revealed the insanity of the perpetrator of the deed. 
Truth often arises from error, but never from confusion.

A double hemiplegia is more than two hemiplegias.

It is absolutely impossible to have functional change in a nerve cell or in nervous tissue without a corresponding structural change, however imperfectly we may be able to appreciate it. It is only in Alice in Wonderland that the Cheshire cat can fade away till there is nothing left of it but the grin. The grin cannot exist by itself, nor can functional change exist by itself.

He had a patient who came from an inn called 'The Crab and Lobster', who was aphasic and always spoke of the 'Lab and Crobster'. It is as though one half of the brain said crab and lobster, and the other half lobster and crab. The incoordinate combination of the two halves of the brain produces lab and crobster.

An aphasic patient of Weir Mitchell's said 'doggo' instead of 'Oh God'. Also 'flute' became 'tufle', 'my cat' became 'takim'. Instances of the compounding of aphasics occur in ordinary life. We pronounce 'stags' as if it were stag-z instead of stag-s. We cannot say stag-s, as a matter of fact. If we try, it becomes stack-s.

He had a story of a man who lived in a place called Ash's Passage. If in the evening he began to talk of Ash's Pashes, he knew he had had enough.

Cases occur where a patient with hemiplegia has fits on the hemiplegic side. The hemiplegia, i.e. the lesion, has destroyed certain movements for ever, hence the palsy. The fit can never bring back movements that are lost. Therefore the movements that take place in the fit on the hemiplegic side are movements that are left in the cortex.

He drew an important distinction between the complexity of a man's brain and the highly ${ }^{1}$ organised state of the dog's. The respiratory centre in man is very highly organised, but it is not at all complex. The automatism of the lower animals shows how highly organised their brains are, not that they are complex. The fact that a man is for ever learning indicates that his brain is not highly organised, while a dog can't learn much because his brain is highly

1 That is, rigidly. J.P.M. organised. Cortical, not medullary centres in man are complex.

\section{III}

The notes of the third conversation are more scrappy than those of the previous ones; it is likely that it took place during another drive, but the locale is not given.

\section{A THIRD CONVERSATION}

\section{July 15, ?1906}

There was a man whose name was Joshua Bug, and he changed his name by deedpoll to Norfolk Howard. Hence in polite conversation a bug is sometimes called a Norfolk Howard. This was à propos of old houses in the Gray's Inn road. The only trouble about old houses is that they are not clean. Do you have bugs in Scotland?

I asked him whether it was tiring to sit for his bust [vide infra], and he said he much preferred driving about to having his hair cut. It is hard work doing nothing. Sitting still is being under restraint, and that is an active inhibitory process.

There is everything in a name, in spite of Shakespeare. I would rather be called Jackson than Pig. But it is a curious thing there is no similar dislike to Hogg. If any old lady will leave me her estate I will take any name you like.

'Bless my soul'-an oath is a dead proposition, with its meaning stolen from it by emotion.

'I found myself giving a cry'-note expression, not 'I gave a cry'.

It is of great importance to distinguish between cleverness and intelligence. Quack advertisements often show great cleverness but little intelligence.

The chief difficulty of an ataxic man is not so much in walking as in starting, stopping, turning. As he becomes more ataxic, these movements become confluent, like those of a drunken man. So in speech, if there is a difficulty in starting or stopping the words tend to become confluent.

\section{COMMENTS}

The bust referred to was presented to the National Hospital by the medical staff and others on the occasion of Dr Jackson's retirement, and stood in the front hall of the Hospital 
for many years; it now stands in the dean's room of the Institute of Neurology. It shows Jackson with a pointed beard and, to that extent, is not a very good likeness of its subject, but it is one of the many indications of the esteem in which Hughlings Jackson was held by his contemporaries. The presentation was made at a small ceremony held in the front hall on 28 November 1907, and Godfrey Hamilton, the secretary of the Hospital, recorded that when Sir William Gowers pulled aside the drapery and exposed the bust he said 'Our Master!' and turned towards Jackson. Gowers was by no means given to compliments.

Many years afterwards (1945) I inquired about this incident from Dr James Taylor, who had worked closely with both these men, and in his reply (which I still have) he wrote, 'I know that Gowers really reverenced Jackson'.

Wilson was perhaps a little disappointed with his conversations and, in any case, felt that he was not in a position to assess what Jackson was like in his prime. At the time of the Jackson centenary (1935) he wrote:

'Those who knew him when he was old and beginning to show signs of failing vigour, cannot really consider themselves in a position to do this; they saw him after his best was over and had little genuine opportunity of judging for themselves in regard to those qualities which had so impressed their seniors.'

The material of these conversations is included in a collection given by Dr Bruce Kinnier Wilson to the Cairns Library, at the Radcliffe Infirmary, Oxford, and I am grateful to the Chairman of the Library Committee for permission to publish it.

\section{REFERENCES}

Critchley, M. (1964). The Black Hole and other Essays, pp. 124-132. Pitman: London.

Wilson, S. A. K. (1935). The Hughlings Jackson centenary. Lancet, 1, 882-883. 